\title{
Allergen-induced IL-9 directly stimulates mucin transcription in respiratory epithelial cells
}

\author{
M. Longphre, ${ }^{1}$ D. Li, ${ }^{1}$ M. Gallup, ${ }^{1}$ E. Drori, ${ }^{1}$ C.L. Ordoñez, ${ }^{1}$ T. Redman, ${ }^{2}$ S. Wenzel, ${ }^{3}$ \\ D. E. Bice, ${ }^{2}$ J.V. Fahy, ${ }^{1}$ and C. Basbaum ${ }^{1}$ \\ ${ }^{1}$ Department of Anatomy and Cardiovascular Research Institute, School of Medicine, University of California-San Francisco, \\ San Francisco, California 94143, USA \\ ${ }^{2}$ Lovelace Respiratory Research Institute, Inhalation Toxicology Laboratory, Albuquerque, New Mexico 87185, USA \\ ${ }^{3}$ National Jewish Hospital, Center for Immunology and Respiratory Disease, Denver, Colorado 80206, USA
}

Address correspondence to: Malinda Longphre, Bristol-Myers Squibb Pharmaceutical Research Institute, PO Box 4000, Princeton, New Jersey, 08543-4000, USA. Phone: (609) 252-5320; Fax: (609) 252-6058; E-mail: longphrm@bms.com.

Received for publication December 18, 1998, and accepted in revised form October 5, 1999.

\begin{abstract}
A hallmark of asthma is mucin overproduction, a condition that contributes to airway obstruction. The events responsible for mucin overproduction are not known but are thought to be associated with mediators of chronic inflammation. Others have shown that T-helper 2 (Th2) lymphocytes are required for mucous cell metaplasia, which then leads to mucin overproduction in animal models of allergy. We hypothesized that Th2 cell mediators are present in asthmatic airway fluid and directly stimulate mucin synthesis in airway epithelial cells. Results in cultured airway epithelial cells showed that samples of asthmatic fluid stimulated mucin (MUC5AC) synthesis severalfold more potently than non-asthmatic fluid. Consistent with this, lavage fluid from the airways of allergen-challenged dogs stimulated mucin synthesis severalfold more potently than that from non-allergen-challenged dogs. Fractionation of dog samples revealed 2 active fractions at $<10 \mathrm{kDa}$ and $30-100 \mathrm{kDa}$. Th2 cytokines in these molecular weight ranges are IL-9 $(36 \mathrm{kDa})$, IL-5 $(56 \mathrm{kDa})$, and IL-13 $(10 \mathrm{kDa})$. Antibody blockade of ligand-receptor interaction for IL-9 (but not IL-5 or IL-13) inhibited mucin stimulation by dog airway fluid. Furthermore, recombinant IL-9, but not IL-5 or IL-13, stimulated mucin synthesis. These results indicate that IL-9 may account for as much as $50-60 \%$ of the mucin-stimulating activity of lung fluids in allergic airway disease.

J. Clin. Invest. 104:1375-1382 (1999).
\end{abstract}

\section{Introduction}

Mucus overproduction is often observed in airway inflammation and is the leading cause of airway obstruction in asthma, chronic bronchitis, and cystic fibrosis (1-4). A key question in the pathogenesis of these illnesses is the extent to which inflammation itself contributes to mucus overproduction. Many studies have shown that inflammatory mediators such as histamine, prostaglandins, leukotrienes, platelet-activating factor, and eosinophil cationic protein can stimulate mucin secretion (5-9). In contrast, only a single study examining a single cytokine (tumor necrosis factor $\alpha[\mathrm{TNF} \alpha]$ ) has provided evidence that inflammatory mediators also stimulate mucin synthesis (10).

Therefore, this study sought to examine the effects of inflammatory mediators on mucin synthesis. Our strategy, based on evidence that inflammatory mediators often act synergistically, was to assay the effect of airway bronchoalveolar lavage (BAL) fluid. BAL fluid contains a mixture of cytokines in their natural concentrations and interrelationships, not merely a single cytokine. We reasoned that any effects of the BAL fluid as a whole could ultimately be resolved at the level of individual cytokines via fractionation and immunochemistry.

In this study, we analyzed fluids from the airways of asthmatic and non-asthmatic humans, as well as fluids from the airways of dogs before and after allergen challenge. Lymphocytes, neutrophils, and eosinophils have all been described as prominent inflammatory cells in the asthmatic airway $(11,12)$. Previous studies characterized the population of lymphocytes in the airways of human asthmatics as activated CD4+ T cells (11-13). Evidence supporting a pathogenic role for this cell type includes animal studies showing that depletion of CD4+ $\mathrm{T}$ cells inhibits antigen-induced airway inflammation (14).

Antigen-activated CD4+ T cells undergo differentiation to either T-helper 1 (Th1) or T-helper 2 (Th2) cells, depending on the presence of specific mediators from other leukocytes (15). These subsets differ functionally, with Th1 cells secreting primarily interferon $\gamma$ and Th2 cells secreting a variety of cytokines, including IL-4, IL5, IL-9, IL-10, and IL-13 (16).

Although there had been correlative evidence linking asthma with Th2 cells (11), it was not until recently that a causal relationship was established (17). In that study, the authors activated lymphocytes in vitro by exposure to ovalbumin under conditions favoring either Th1 or Th2 differentiation. They then showed that mice receiving Th2 cells (but not Th1 cells), that had also inhaled ovalbumin, contained abundant mucous cells and intraluminal mucus in their airways. This, along with results showing that overexpression of the Th2 cytokines IL-4, IL-5, or IL-9 in mouse airways leads to an increase in airway mucous cells (18-20), strongly suggested that Th2 cytokine(s) is required for the production of mucus in asthma. However, it could not be concluded whether such a cytokine stimulates epithelial cells directly or acts indirectly through another cell type. 
The experiments described in this article indicate that the Th2 cytokine IL-9 acts directly on epithelial cells to stimulate mucin transcription, and they suggest that analysis of the IL-9-triggered mucin response may reveal new antihypersecretion drug targets.

\section{Methods}

Cell culture. All tissue culture media and supplies were obtained from GIBCO BRL (Grand Island, New York, USA) or Clonetics (San Diego, California, USA). A human pulmonary mucoepidermoid carcinoma cell line, NCI-H292, was purchased from the American Type Culture Collection (Rockville, Maryland, USA) and maintained in RPMI-1640 with $2 \mathrm{~g} / \mathrm{L}$ glucose, $0.3 \mathrm{~g} / \mathrm{L}$ L-glutamine, $2 \mathrm{~g} / \mathrm{L} \mathrm{NaHCO} 3,10 \%$ fetal calf serum, $100 \mathrm{U} / \mathrm{mL}$ penicillin, and $100 \mathrm{mg} / \mathrm{mL}$ streptomycin at $37^{\circ} \mathrm{C}$ in $5 \%$ $\mathrm{CO}_{2}$. Human primary bronchial epithelial cells (Clonetics) were maintained in bronchial epithelial basal medium (BEBM) with added growth factors according to the recommendations of the supplier. Both cell types express receptors for IL-5, IL-9, and IL-13 as determined by RTPCR of whole-cell RNA (see below).

For function-blocking antibody experiments, antibodies to cytokine receptors were purchased from R\&D Systems Inc. (Minneapolis, Minnesota, USA) or Chemicon International (Temecula, California, USA) and used at concentrations recommended by the manufacturers (1-3 $\mu \mathrm{g} / \mathrm{mL}$ ). We immunoprecipitated cytokines from experi-

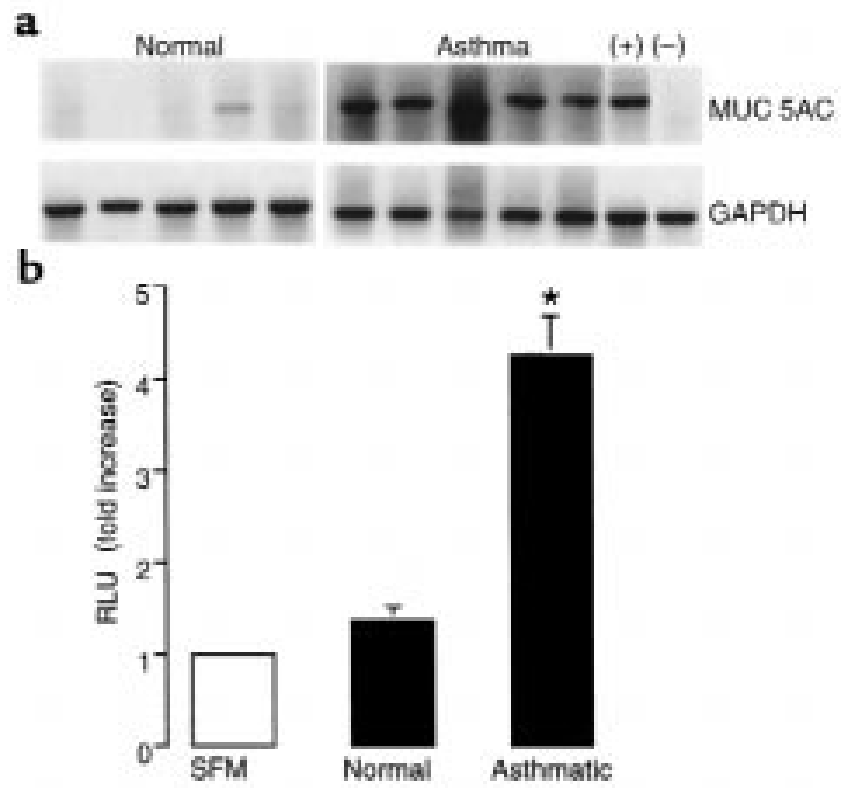

Figure 1

Human tracheal aspirates from asthmatics induce MUC5AC in airway epithelial cells in culture. (a) $\mathrm{NCl}-\mathrm{H} 292$ cells were treated for 8 hours with aspirates from 5 healthy control (Normal) and 5 asthmatic human subjects. Cells used as negative (-) controls were in SFM and cells used as positive $(+)$ controls were exposed to vanadate. RT-PCR was performed using primers for MUC5AC and GAPDH. (b) NCI-H292 cells were transfected with the 3.7-kb MUC5AC luciferase construct and challenged with asthmatic or non-asthmatic tracheal aspirates for 16 hours. RLU, relative luciferase units. Bars represent means $\pm \operatorname{SEM}(n=5$ patients/group in duplicate). ${ }^{*}$ Significantly different from SFM control; $P<0.05$ mental medium using standard methods and cytokineor receptor-specific antibodies (R\&D Systems Inc.).

Human tracheal aspirates. Tracheal aspirates were obtained from subjects recruited from Moffitt-Long and San Francisco General Hospital (University of California-San Francisco, San Francisco, California, USA). Medical consent was obtained, and a medical questionnaire was filled out for each patient. Subjects who had smoked cigarettes or used any other recreational inhalant in the past 10 years were excluded from the study. Also excluded were subjects who had evidence of congestive heart failure or who had a history of lung disease other than asthma. Five patients (4 women, 1 man; mean age $39.8 \pm 6.9$ SEM) diagnosed as having acute severe asthma by intensive care physicians, and who had been intubated for the management of their asthma, and 5 patients ( 2 women, 3 men; mean age $32.8 \pm$ 5.4 SEM) undergoing delivery of general anesthesia for nonpulmonary surgical procedures all had tracheal aspirates collected $0-12$ hours after intubation. Standard clinical methods were used for collecting tracheal aspirates from healthy and asthmatic subjects in this study. A 30$\mathrm{cm}$ thin plastic catheter (Suction Catheter Kit; Kendall Health Care Products Company, Mansfield, Massachusetts, USA) was passed through the endotracheal tube and into the airway. Mucus was aspirated into a clean plastic container. Aspirate volume was determined and mixed with an equal volume of sterile saline. This was then diluted with saline containing DTT $(10 \%$ sputolysin $[0.01 \%$ final concentration]; Behring Diagnostics Inc., Somerville, New Jersey, USA). The aspirated sample (now diluted 1:4 from the original sample) was incubated in a shaking water bath at $37^{\circ} \mathrm{C}$ for 15 minutes. The samples were then centrifuged at $1,037 \mathrm{~g}$ for 5 minutes, and the supernatants were stored at $-70^{\circ} \mathrm{C}$. We exposed NCI-H292 cells to human tracheal aspirates diluted 1:6 with culture medium for 8 hours. We harvested cultured cell RNA and monitored it for the presence of MUC5AC mRNA by RT-PCR. MUC5AC transcriptional activity was evaluated after 16 hours by measuring luciferase activity (see below).

Allergic dog lavage. Dogs were sensitized as pups with ragweed antigen and 1 lung in each of 5 adult dogs was challenged with ragweed. See Collie et al. (21) for detailed sensitization, challenge, and lavage procedures. Challenges were followed by timed bronchoalveolar lavages. For the present study, we focused on the "3-day pre-challenge" and the "4-day post-challenge" samples as these showed the greatest difference in in vitro mucininducing activity in preliminary screens. NCI-H292 cells were transfected with MUC5AC luciferase(see below) and treated with dog lavage samples diluted 1:3 with serumfree RPMI. Macrosep centrifugal concentrators (Pall Filtron Corp., Northborough, Massachusetts, USA) were used for fractionation of lavage fluids by molecular weight $(100 \mathrm{kDa}, 30 \mathrm{kDa}, 10 \mathrm{kDa}$, and $3 \mathrm{kDa})$ according to manufacturer's recommendations. The Macrosep device was rinsed with buffer, loaded with biological fluid, and then centrifuged at 3,000-5,000 $\mathrm{g}$ for 60-90 minutes. All retentates were then volume corrected with PBS to maintain original concentration of the retained molecules. Some lavage samples were incubated with proteinase $\mathrm{K}$ (1:20, proteinase/protein ratio) at $60^{\circ} \mathrm{C}$ for 1 hour followed by 15 minutes of boiling to determine whether the 


\section{Figure 2}

Ragweed-challenged dog lavage stimulates MUC5AC reporter in airway epithelial cells in culture. $\mathrm{NCl}-\mathrm{H} 292$ cells were transfected with the 3.7-kb MUC5AC luciferase construct and challenged with BAL for 16 hours. $\mathrm{RW}$, ragweed. Bars represent means \pm $\operatorname{SEM}(n=4$ dogs in triplicate). *Significantly different from SFM control; $P<0.05$.

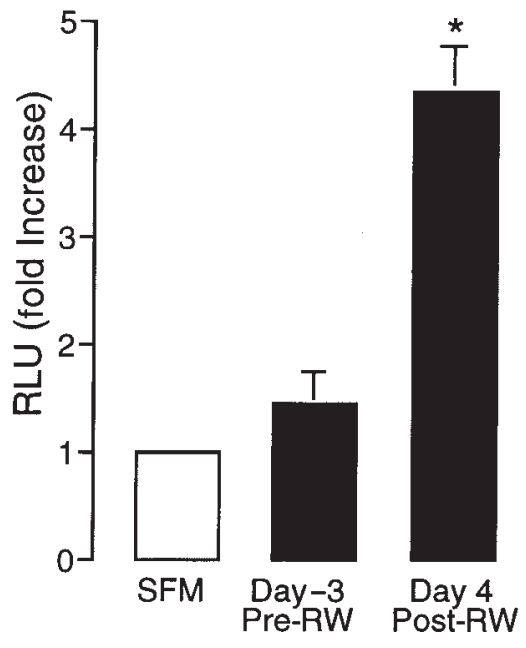

active factor was a protein. Negative controls consisting of PBS with proteinase $\mathrm{K}$ alone were used to determine possible effects of proteinase $\mathrm{K}$ on mucin transcription.

$R T-P C R$. Reverse transcription of RNA to cDNA was carried out using the following reaction mixture: $5 \mu \mathrm{g}$ total RNA from each sample in $8 \mu \mathrm{L}$ diethyl cyanophosphate-treated (DEPC) water, $4 \mu \mathrm{L} 5 \times$ first strand buffer (GIBCO BRL), $2 \mu \mathrm{L} 10 \mathrm{mM}$ deoxynucleotide triphosphate (dNTP) (GIBCO BRL), $2 \mu \mathrm{L} 0.1 \mathrm{M}$ DTT (GIBCO BRL), $1 \mu \mathrm{L}$ RNase inhibitor (40 U; Roche Molecular Biochemicals, Indianapolis, Indiana, USA), $2 \mu \mathrm{L} 10 \times$ hexonucleotides (Roche Molecular Biochemicals), and $1 \mu \mathrm{L}$ SuperScript II (GIBCO BRL). The reaction mixture was incubated at $37^{\circ} \mathrm{C}$ for 1 hour, then at $75^{\circ} \mathrm{C}$ for 15 minutes, and stored at $4^{\circ} \mathrm{C}$. PCR was carried out using Ready-To-Go PCR Beads (Pharmacia Biotech Inc., Piscataway, New Jersey, USA) in a $25-\mu \mathrm{L}$ reaction mixture containing: $1.5 \mathrm{U}$ Taq polymerase, $10 \mathrm{mM}$ Tris$\mathrm{HCl}$ ( $\mathrm{pH} 9.0$ at room temperature), $50 \mathrm{mM} \mathrm{KCl}, 1.5$ $\mathrm{mM} \mathrm{MgCl}, 200 \mu \mathrm{M}$ of each dNTP and stabilizers, including BSA, $0.2 \mu \mathrm{M}$ of each primer, and $1 \mu \mathrm{L}$ of RTPCR reaction product. Custom primers were obtained from Life Technologies (Gaithersburg, Maryland, USA). Human GAPDH primers were 3': GGG GTC TAC ATG GCA ACT GTG AGG AGG GGA and 5': AAA CCT GCC AAA TAT GAT GAC ATC AAG AAG; human MUC5AC primers 3': TCA CAG CCG GGT ACG CGT TGG CAC AAG TGG and 5': TGC TAT TAT GCC CTG TGT AGC CAG GAC TGC; human IL-9 receptor (IL-9R) $\alpha$ primers were 3': TGC CTG ACA AAC TCA GTG CCA CAC TGG and 5': CCT GTG TGA ACC TGT CGT GCA AAG CTCA; human IL$13 R \alpha$ primers were $3^{\prime}:$ GCC CTT GTT AAG ATC AAA CCC ATC and $5^{\prime}$ : TGA GTC TAA CGG TCT TCC GGA TGAA; human IL-5R $\alpha$ primers were 3': CAA CAA GCC AGG TGC AGT GAAG and 5': CCA CTG AGA TAC TGC AAG CTG AC. We used a standard PCR protocol: 5 minutes at $95^{\circ} \mathrm{C}$ followed by 35 cycles of 30 seconds at $95^{\circ} \mathrm{C}, 30$ seconds at either $60^{\circ}$ or $55^{\circ} \mathrm{C}$ (depending on the annealing temperature of the primers), and 60 seconds at $72^{\circ} \mathrm{C}$. After cycling, the samples were kept at $72^{\circ} \mathrm{C}$ for $20 \mathrm{~min}$ utes and stored at $4^{\circ} \mathrm{C}$. Samples were run on a $1.2 \%$ agarose gel containing ethidium bromide for visualization under an ultraviolet lamp.
Luciferase assay. Approximately $3.7 \mathrm{~kb}$ of the $5^{\prime}$ flanking region of the human MUC5AC gene (22) was cloned into pGL3-Basic luciferase vector (Promega Corp., Madison, Wisconsin, USA). NCI-H292 cells were seeded in 6-well tissue culture plates $\left(10^{6}\right.$ cells/well $)$ and left for 18 hours in complete growth medium. Lipofectamine (GIBCO BRL) transfection of cells was done in accordance with the instructions of the manufacturer. Briefly, $1 \mu \mathrm{g}$ DNA, $0.8 \mu \mathrm{g}$ histone, and $2 \mu \mathrm{g}$ Lipofectamine in $1 \mathrm{~mL}$ OPTIMEM (GIBCO BRL) reduced serum medium was added to each well. After 4 hours, the OPTIMEM medium was replaced with complete growth medium and the cells allowed to recover overnight. Luciferase activity was measured according to manufacturer's recommendations (Promega Corp.). Briefly, $250 \mu \mathrm{L}$ of lysis buffer (Promega Corp.) was added to each well and plates were agitated for 1 hour at room temperature. The wells were then scraped with a rubber cell scraper, and the contents of the wells were transferred into $1.5-\mathrm{mL}$ tubes and briefly centrifuged to remove cell debris. Twenty microliters of supernatant was added to $100 \mu \mathrm{L}$ luciferase assay reagent and light units measured for 30 seconds on a Monolight 2010 luminometer (Analytical Luminescence Laboratory, San Diego, California, USA). All transfections were carried out in triplicate. Luciferase activity was normalized with respect to relative light units emitted from serum-free, medium-treated controls.

ELISA. Serial dilutions of each dog lavage or human aspirate sample were plated in duplicate on 96-well microtiter plates (Immulon; PGC Scientific, Gaithersburg, Maryland, USA). Wells containing no sample served as negative controls, and wells containing recombinant human IL-9, IL-5, or IL-13 (R\&D Systems Inc.) served as positive controls and concentration standards on each plate. Antigen was dried onto the plates

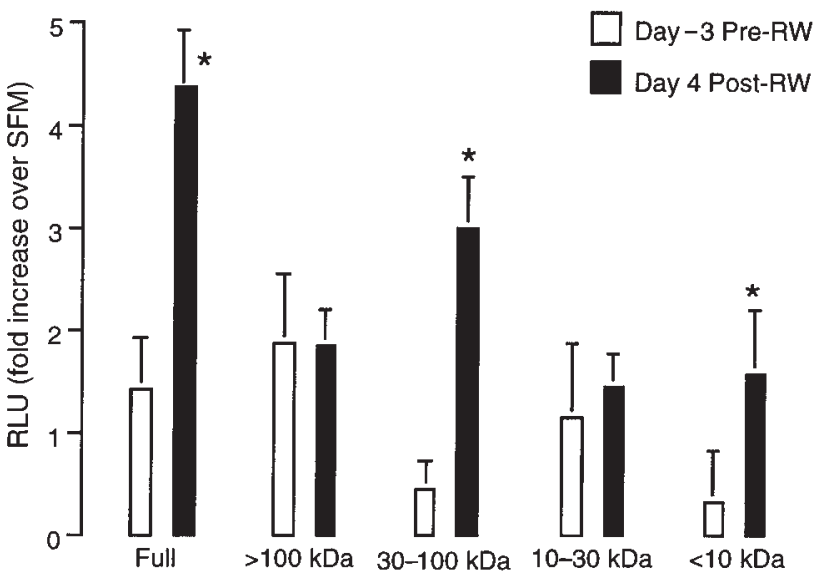

Figure 3

Fractionated dog lavage stimulates MUC5AC reporter in airway epithelial cells in culture. NCl-H292 cells were transfected with the 3.7-kb MUC5AC luciferase construct and challenged with BAL for 16 hours. Bars represent means ( $n=4$ dogs in duplicate). 


\section{Figure 4}

Demonstration of receptor RNA for IL-9, IL-5, and IL-13 in $\mathrm{NCl}-\mathrm{H} 292$ airway epithelial cell line (H292) and primary cultures of human primary bronchial epithelial cells (HBE) by RT-PCR of unique receptor $\alpha$ subunits.

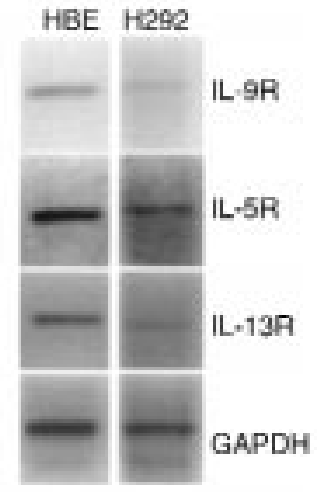

overnight at $40^{\circ} \mathrm{C}$. Plates were then treated with $1 \%$ normal rabbit serum/PBS/Tween 20 (RPT) for 1 hour before incubation with primary antibody for 2 hours at room temperature. Antigen-coated wells were incubated with $1 \mu \mathrm{g} / \mathrm{mL}$ goat anti-human IL-9, IL-5, or IL-13 antibody (R\&D Systems Inc.). The plates were then washed 3 times with RPT. Plates were then incubated with a 1:200 dilution of biotinylated rabbit anti-goat IgG (Vector Laboratories, Burlingame, California, USA) for 2 hours at room temperature. All plates were then washed 3 times with RPT and incubated (1 hour at room temperature) with an avidin/alkaline phosphatase conjugate (ABC-AP; Vector Laboratories). After washing, wells were incubated $\left(15\right.$ minutes, $\left.37^{\circ} \mathrm{C}\right)$ with 1 $\mathrm{mg} / \mathrm{mL}$ para-nitrophenyl phosphate (Sigma Chemical Co., St. Louis, Missouri, USA) in Tris buffer ( $\mathrm{pH}$ 7.2). Absorbance at $492 \mathrm{~nm}$ was determined on a Titertek Multiskan MC microplate reader (Eflab Oy, Helsinki, Finland). IL-9 concentrations were determined from a standard curve. The lower detection limits for ELISAs were between 8 and $16 \mathrm{pg} / \mathrm{mL}$ for IL-9; 31 and $63 \mathrm{pg} / \mathrm{mL}$ for IL-13; and 63 and $125 \mathrm{pg} / \mathrm{mL}$ for IL-5.

Ribonuclease protection assay (RPA). A PCRII plasmid (Invitrogen Corp., San Diego, California, USA) containing MUC5AC (clone $298 \mathrm{BP}$ ) or cyclophilin was linearized with the appropriate restriction enzyme in a $100-\mu \mathrm{L}$ volume overnight at $37^{\circ} \mathrm{C}$ to give the antisense strand. The enzyme was then digested with the addition of $5 \mu \mathrm{L}$ of $10 \%$ SDS and $1 \mu \mathrm{L}$ proteinase $\mathrm{K}(10 \mathrm{mg} / \mathrm{mL})$ at $65^{\circ} \mathrm{C}$ for 15 minutes before phenol/chloroform/isoamyl alcohol extraction. The extract was precipitated with $50 \mu \mathrm{L}$ of 5
$\mathrm{M}$ ammonium acetate and $450 \mu \mathrm{L}$ ethanol for 15 minutes at $-80^{\circ} \mathrm{C}$. The pellet was redissolved in $20 \mu \mathrm{L}$ DEPC water. Riboprobe was synthesized with $5 \mu \mathrm{L} 5 \times$ transcription buffer, $10 \mu \mathrm{M}$ cold NTPs, $10 \mu \mathrm{M}$ DTT, $40 \mathrm{U}$ RNase inhibitor, $50 \mu \mathrm{Ci} \alpha^{32} \mathrm{P}$-labeled UTP $(400 \mathrm{Ci} / \mathrm{mM})$, DEPC water, $2 \mu \mathrm{L}$ linearized and purified DNA template, and $1 \mu \mathrm{L}$ of $\mathrm{T} 7$ polymerase at $37^{\circ} \mathrm{C}$ for 1 hour. RNase-free DNase I was then added at $37^{\circ} \mathrm{C}$ for 30 minutes. The probe was then ethanol precipitated twice. The pellet was resuspended in $8 \mu \mathrm{L}$ of gel-loading buffer. To purify the probe, it was run on a $0.75-\mathrm{mm}$-thick $6 \%$ polyacrylamide/ $8 \mathrm{M}$ urea gel at $1,000 \mathrm{~V}$ for $30 \mathrm{~min}$. The target band on the gel was located by exposing the gel on film for 15 seconds. The band was excised and incubated in elution buffer (RPA II kit; Ambion Inc., Austin, Texas, USA) at $37^{\circ} \mathrm{C}$ overnight. The RNA samples were reprecipitated and redissolved in $20 \mu \mathrm{L}$ of $1 \times$ hybridization buffer ( $80 \%$ formamide/20\% $5 \times$ hybridization buffer). The purified probe was diluted in $1 \times$ hybridization buffer so that each sample would have $500,000 \mathrm{cpm}$. After $10 \mu \mathrm{L}$ of the probe was added, the samples were heated at $95^{\circ} \mathrm{C}$ for 5 minutes before hybridizing at $45^{\circ} \mathrm{C}$ overnight. After hybridization, $200 \mu \mathrm{L}$ of diluted RNase A and T (RPA II kit; Ambion Inc.) was added to each sample, and they were incubated at $37^{\circ} \mathrm{C}$ for $30 \mathrm{~min}$. The samples were precipitated and redissolved in $4 \mu \mathrm{L}$ gel-loading buffer. The samples were then denatured at $95^{\circ} \mathrm{C}$ for 5 minutes before running on a 0.5 -mm-thick $6 \%$ polyacrylamide $/ 8$ $\mathrm{M}$ urea gel at 1,500 $\mathrm{V}$ for 2 hours. The gel was dried and exposed to X-omat AR film (Eastman Kodak Co., Rochester, New York, USA) at $-80^{\circ} \mathrm{C}$ for $2-7$ days.

Bronchial biopsies. All biopsies were performed with informed consent of the study participants by S.W. (National Jewish Hospital, Denver, Colorado, USA). Five asthmatic individuals and 5 normal controls participated. The bronchoscope was passed nasally, and 6 endobronchial biopsies were taken from the first and second subcarinae of the right or left lower lobes. Endobronchial tissue was fixed overnight at $-20^{\circ} \mathrm{C}$ in acetone, and then embedded in glycol methacrylate resin. Tissue blocks were stored at $-20^{\circ} \mathrm{C}$ until $2-\mu \mathrm{m}$ sections were cut using a Reichert Ultracut E ultramicrotome (Leica Microsystems Inc., Deerfield, Illinois, USA). Tissue sections were treated with trypsin at $37^{\circ} \mathrm{C}$ for 10 minutes and rinsed in PBS containing $0.05 \%$ Tween 20 . The tissue was blocked with normal horse serum for 20 minutes and incubated

\section{Figure 5}

Demonstration of cytokines in dog airway lavage and human airway aspirate. (a) ELISA showing IL-5, IL-9, and IL-13 in post-RW lavage compared with preRW lavage. (b) ELISA showing IL-5, IL-9, and IL-13 in normal and asthmatic aspirates. Bars represent means $\pm \operatorname{SEM}(n=$ 4 in duplicate). *Significantly different from pre-RW (a) or normal (b) control.

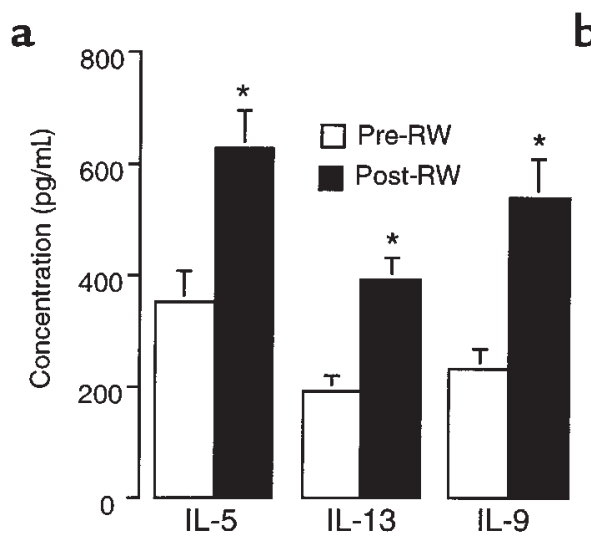

b

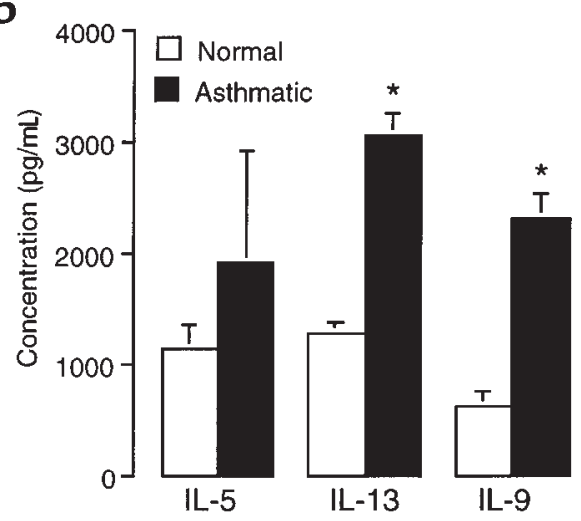




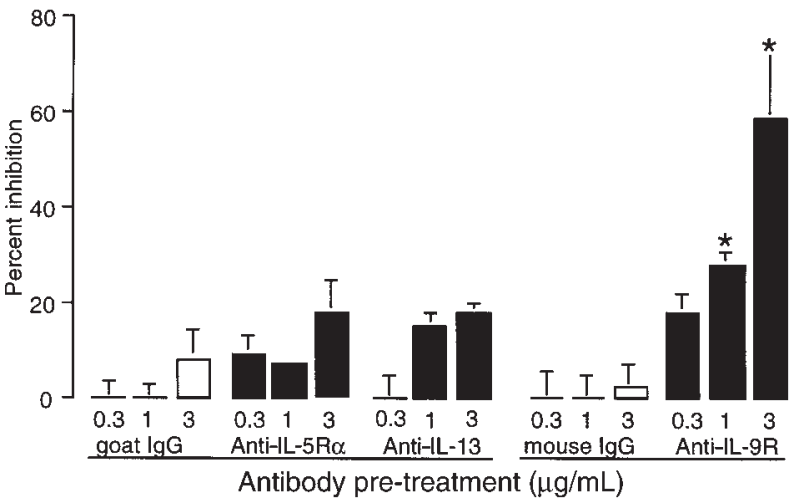

Figure 6

The effect of cytokine antibody or cytokine receptor antibody pretreatment on MUC5AC luciferase activity elicited by day 4 post-ragweed dog lavage. $\mathrm{NCl}-\mathrm{H} 292$ cells were transfected with the 3.7-kb MUC5AC luciferase construct and challenged with BAL for 16 hours. Bars represent means \pm SEM $(n=3$ wells in duplicate). * Significantly different from isotype control; $P<0.05)$.

in either anti-IL-9R (R\&D Systems Inc.) or isotype control (anti-trinitrophenol; PharMingen, San Diego, California, USA) for 2 hours. After washing in PBS/Tween 20, the tissue was treated with a secondary biotinylated antimouse IgG (Vector Laboratories) for 1 hour and washed again. The tissue was then incubated with avidin-HRP conjugate (Vector Laboratories) for 30 minutes and washed thoroughly. The slides were then developed with diaminobenzidine tetrahydrochloride (DAB) (Vector Laboratories) for 4 minutes at room temperature and counterstained with hematoxylin (Sigma Chemical Co.).

Intratracheal instillation of IL-9 in mice. Female (age 8 weeks, weighing 20-23 g) C57BL6/J mice were purchased from The Jackson Laboratory (Bar Harbor, Maine, USA). Mice were anesthetized with Avertin (2.5\% solution, 0.15 $\mathrm{mL} / 10 \mathrm{~g}$ intraperitoneally). The trachea was surgically exposed by making a $1.5-\mathrm{cm}$ incision in the skin and carefully separating the thyroid gland and overlying strap muscles. A $100-\mu \mathrm{L}$ volume of rmIL-9 $(10 \mu \mathrm{g} / \mathrm{mL}$ in PBS; R\&D Systems Inc.), or PBS was instilled into the trachea using a 27-gauge needle. The incision was closed with surgical silk, and the mice were observed until they recovered from anesthesia (usually 1 hour). The mice were returned to filter-topped, autoclaved cages for 1 week with free access to food and water.

The mice were sacrificed by cervical dislocation, and their lungs were excised and fixed by perfusion through the trachea with $4 \%$ paraformaldehyde at a constant pressure of $20 \mathrm{~cm} \mathrm{H}_{2} \mathrm{O}$. After 2 hours perfusion-fixation, the lungs were immersed in a large volume of the same fixative overnight. Tissues were embedded in paraffin, sectioned $(5 \mu \mathrm{m})$, and then stained with periodic acid/Schiff reagent (PAS) and hematoxylin.

The trachea and main stem bronchi were the focus of study as these airways have a quantifiable population of mucin-producing goblet cells, and these airway structures are easily identifiable in section. We obtained measurements from 17-19 cross sections of the main stem bronchi from each mouse and 14-16 longitudinal sections of each trachea taken at $20-\mu \mathrm{m}$ intervals. Using $\times 400$ magnification, all PAS-positive cells lining the trachea and main stem bronchi were counted. The length of the basal lamina for each sectioned airway was determined using a computerized sterology system that used software capable of making calibrated linear measurements from contour tracings (Stereoinvestigator; Microbrightfield Inc., Colchester, Vermont, USA). The data for each group were expressed as the mean number of PAS-positive cells per millimeter of basal lamina.

Statistical analysis. Experimental data were evaluated by one- or two-way analysis of variance (23). Student-Newman-Keuls post-hoc comparison of means (23) was used to further assess significance. Significance was defined as $P<0.05$.

\section{Results}

Upregulation of MUC5AC by asthmatic airway fluid. Exposure to tracheal aspirates from asthmatic and non-asthmatic patients caused MUC5AC mRNA (Figure 1a) and transcriptional activity (Figure 1b) to increase in NCI-H292 cells. The increase in transcriptional activity was severalfold greater in response to asthmatic aspirates when compared with non-asthmatic aspirates.

Because of difficulties inherent in obtaining and working with human samples, we evaluated the possibility of using allergic airway fluids from animals. Results showed that dog bronchoalveolar lavage, like human airway fluid, stimulated MUC5AC transcription; postchallenge (ragweed) lavage was severalfold more potent than pre-challenge lavage (Figure 2). Stimulation by both human and dog lavage was inhibited by proteinase $\mathrm{K}$ treatment of the lavage samples (not shown), thus indicating that the active factors in both human and dog samples were proteins.

Fractionation of dog lavage samples revealed activities in fractions containing molecules between 30 and 100 $\mathrm{kDa}$ and less than $10 \mathrm{kDa}$ (Figure 3). The stimulatory effect of full medium could be essentially reconstituted by combining the effects of the 30-100 and less than 10 $\mathrm{kDa}$ fractions, which contributed $62 \%$ and $32 \%$, respectively, to the overall response. Based on data published previously implicating Th2 mediators in allergy-associated mucin production (17), we selected those Th2 cytokines between $30-100 \mathrm{kDa}$ and $<10 \mathrm{kDa}$ (i.e. IL-5, 9, or 13) as candidate pro-mucin cytokines (Table 1).

\section{Table 1}

Known cytokines categorized by molecular weights (based on review by Curfs et al. [17]). Categories reflect the molecular weight cutoffs used for fractionation. Th2-type cytokines are boldfaced.

\begin{tabular}{|c|c|c|c|}
\hline$\geq 100$ & $\leq 100$ & $\leq 30$ & $\leq 10$ \\
\hline TNF $\beta=20-180 \mathrm{kDa}$ & $\begin{array}{l}\mathrm{IL}-5=50 \mathrm{kDa} \\
\mathrm{IL}-9=39 \mathrm{kDa} \\
\mathrm{IL}-12=76 \mathrm{kDa} \\
\mathrm{IL}-14=60 \mathrm{kDa} \\
\mathrm{IL}-16=56 \mathrm{kDa} \\
\mathrm{IL}-17=38 \mathrm{kDa}\end{array}$ & $\begin{array}{c}\mathrm{IL}-1=18 \mathrm{kDa} \\
\mathrm{IL}-1 \mathrm{ra}=18 \mathrm{kDa} \\
\mathrm{IL}-2=20 \mathrm{kDa} \\
\mathrm{IL}-\mathbf{3}=\mathbf{1 5 - 4 0 ~} \mathbf{k D a} \\
\mathrm{IL}-\mathbf{4}=\mathbf{1 4} \mathbf{~ k D a} \\
\mathrm{IL}-6=26 \mathrm{kDa} \\
\mathrm{IL}-7=22 \mathrm{kDa} \\
\mathrm{IL}-10=\mathbf{1 8} \mathbf{k D a} \\
\mathrm{IL}-11=24 \mathrm{kDa} \\
\mathrm{IL}-15=24 \mathrm{kDa} \\
\mathrm{TGF}=25 \mathrm{kDa} \\
\text { TNF } \alpha=17 \mathrm{kDa}\end{array}$ & $\begin{aligned} \mathrm{IL}-8 & =8 \mathrm{kDa} \\
\mathrm{IL}-13 & =10 \mathrm{kDa}\end{aligned}$ \\
\hline
\end{tabular}


A prerequisite for testing the pro-mucin effects of these cytokines was evidence showing that receptors for all 3 cytokines were present on airway epithelial cells. We found that NCI-H292, the epithelial cell line used in our transcription assays, synthesizes RNA encoding receptors for IL-9, IL-5, and IL-13 at approximately the same levels as those seen in primary bronchial epithelial cells (Figure 4). ELISA analysis in dog tracheal lavage and showed that all 3 cytokines were increased in lavage fluid in response to ragweed challenge (Figure 5a). In addition, the levels of IL9 and IL-13 were elevated in asthmatic compared with normal human tracheal aspirates (Figure 5b).

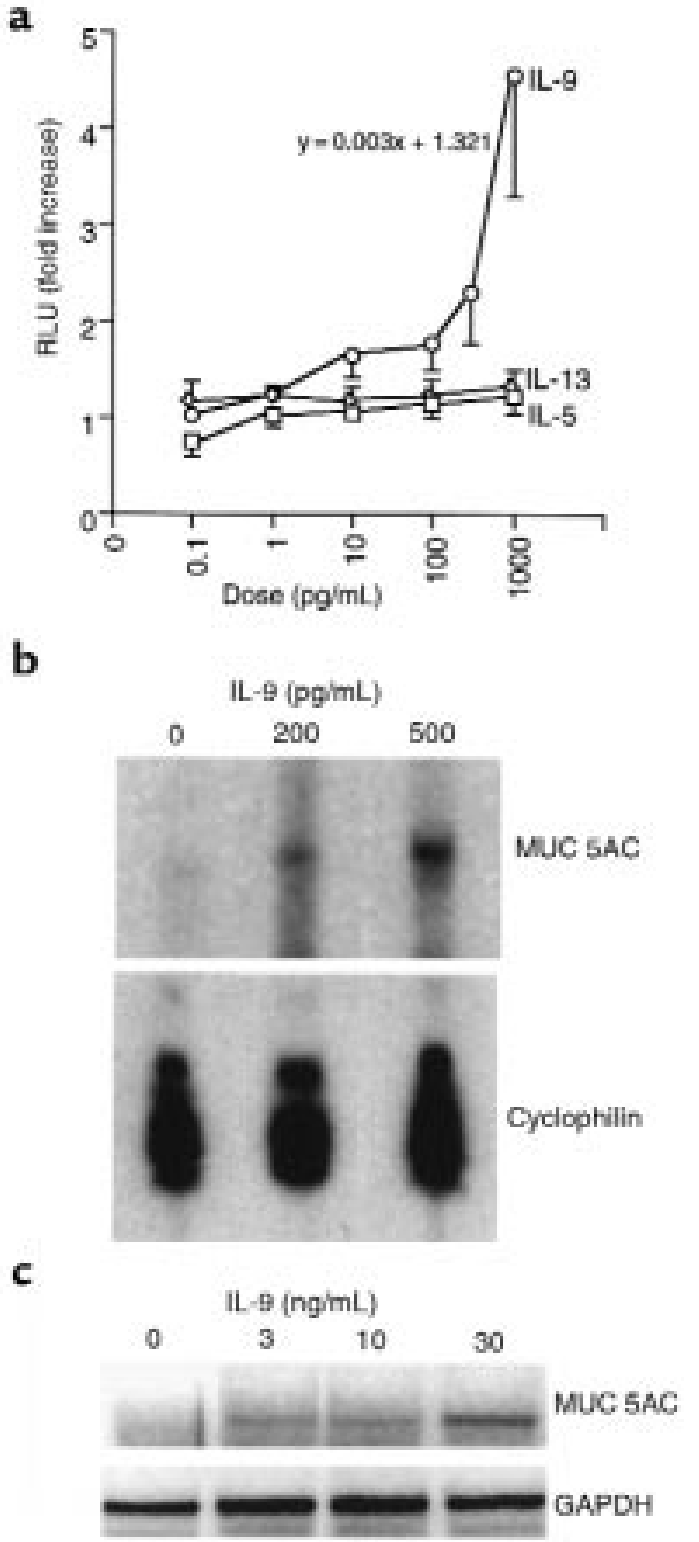

Figure 7

The effect of recombinant human cytokines on MUC5AC. (a) NCI-H292 cells were transfected with the 3.7-kb MUC5AC luciferase construct and challenged with rhIL-9 (circles), rhIL-5 (squares), or rhIL-13 (triangles) for 14-16 hours. Bars represent means $\pm \operatorname{SEM}(n=3$ wells in triplicate). (b) Steady-state MUC5AC and cyclophilin were measured by RPA in NCl-H292 cells treated with IL-9. (c) MUC5AC and GAPDH mRNA were also quantified by RT-PCR in human primary bronchial epithelial cells treated with rhIL-9.
To examine the role of cytokines IL-9, IL-5, and IL-13 in mucin stimulation, we exposed epithelial cells to dog BAL in the presence of function-perturbing antibodies directed against 2 IL receptors (hIL-5R $\alpha$ or hIL-9R), or against the cytokine IL-13. Neither anti-IL5R $\alpha$ nor antiIL13 significantly inhibited the effect of dog BAL on MUC5AC transcription ( $P>0.05$ for both, Figure 6$)$. In contrast, anti-IL-9R attenuated the dog BAL effect in a concentration-dependent manner by up to $60 \%(P<0.05$; Figure 6). Isotype controls, mouse IgG and goat IgG, had no effect $(P>0.05$; Figure 6$)$. Consistent with the results obtained using anti-receptor antibodies, human recombinant IL-9, but not IL-5 or IL-13, increased MUC5AC transcription (Figure 7a). The effect was dose-dependent $\left(\right.$ Luciferase $=(0.003)($ dose $\left.)+1.321 ; r^{2}=0.976\right)$. Recombinant human IL-9 increased MUC5AC message in NCIH292 cells as measured by RPA (Figure 7b). A similar increase in MUC5AC steady state was observed when human primary bronchial epithelial cells were treated with rhIL-9 (Figure 7c).

Demonstration of IL-9R in buman airway epithelium and NCIH292 cells. Bronchial biopsies were immunohistochemically stained for the presence of IL-9R (Figure 8, a and b). Pseudostratified epithelial cells had the greatest degree of immunoreactivity, but staining was also associated with the endothelium of small blood vessels and smooth muscle fibers in the lamina propria. There were no obvious differences in the degree of IL-9R epithelial staining between the normal and asthmatic biopsies. To confirm that our cell line also expressed IL-9R protein, Western blots were performed using cellular extracts from NCI-H292 cells and K562 human lymphoblasts (positive control) (Figure 8c).

Upregulation of goblet cell concentration by IL-9 in mouse tracheas. Tracheal instillation of rmIL-9, but not the PBS vehicle, significantly increased the number of PAS-positive cells in both the trachea and main stem bronchi of mice (Figure 8$)(n=3$ animals per group; $P<0.05)$.

\section{Discussion}

Mucin overproduction is a common feature of asthma and an important contributor to airway obstruction. The strong correlation between mucus overproduction and inflammation in asthma suggests that inflammation might directly stimulate mucin synthesis. Recently, this was supported by animal studies that went on to identify Th2 cells as being instrumental in the generation of mucin-containing epithelial cells in allergic airways (17, 24). That study did not, however, indicate whether Th2 mediators acted directly to stimulate mucin production in epithelial cells or acted through an intermediate cell type.

Here we analyzed the airway fluid of asthmatic subjects to identify factors that can directly stimulate mucin transcription. Using a human MUC5AC mucin transcription assay and differential filtration we found major activities between 30 and $100 \mathrm{kDa}$ and below $10 \mathrm{kDa}$. Based on results from Cohn et al. (24), we focused on Th2 cytokines in these size ranges (IL-5, IL-13, and IL-9). In a series of experiments using cytokine- and cytokine receptor function-perturbing antibodies, we observed inhibition of the mucin-stimulating effect of dog airway fluid by an antibody inhibiting the effects of IL-9, but not IL-5 and IL-13. Support for the hypothesis that IL-9 

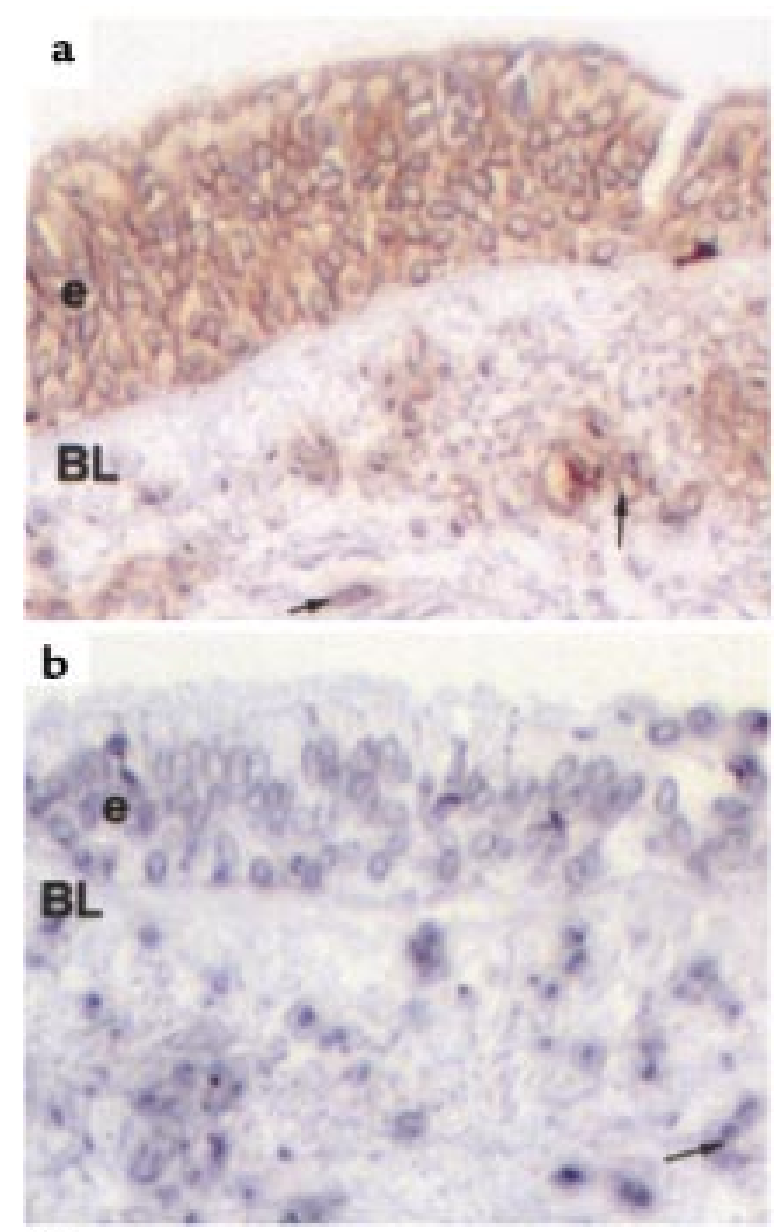

c

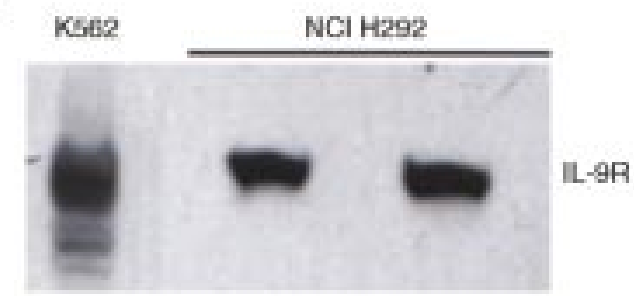

Figure 8

IL-9R is found in the human airway. Bronchial biopsies were immunostained for the presence of IL-9R with DAB (brown) and counterstained with hematoxylin (purple). (a) A representative slide ( $\times 40$ magnification) is shown; the receptor for IL-9 was found dispersed throughout the pseudostratified bronchial epithelium (e) and in the lamina propria associated with vascular endothelium (arrow). The basal lamina (BL) is also indicated for reference. (b) An Ig isotype control (anti-trinitrophenol) showed no DAB staining. (c) The IL-9 receptor was also shown by Western blot and immunostaining to be present on $\mathrm{NCl}-\mathrm{H} 292$ cells in culture.

does directly stimulate mucin transcription, whereas IL5 and IL-13 do not, was provided by results from the converse experiment in our reporter assay showing that recombinant human IL-9 did stimulate mucin transcription, whereas IL-5 and IL-13 did not.

However, IL-9 may not be the only substance in asthmatic airway fluid contributing to mucin production. Although we could stimulate MUC5AC transcription with physiologic doses of rhIL-9, our receptor blocking data showed that anti-IL-9R inhibited only approximately $50 \%-60 \%$ of the effect of post-challenge dog BAL treat- ment. Our data therefore suggest the presence of additional stimulatory factors and possibly inhibitors of IL9/IL-9R in the lavage fluid.

The identity of accessory factors remains unknown. Obvious sources are proteins other than Th2 cytokines present in the active fractions of airway fluid. For example, IL-8 $(8 \mathrm{kDa})$ was abundant in our asthmatic samples and could contribute to mucin stimulation. However, this is unlikely based on our data showing that rhIL-8 fails to stimulate mucin transcription (data not shown). Thus, there are pro-mucin factors yet to be defined in allergic BAL. Isolating and characterizing these accessory pro-mucin factors will be the object of future studies.

The Th2 cytokines IL-4, IL-5, and IL-9 are regarded as pro-mucin agents because airway overexpression of these 3 cytokines is correlated with the appearance of an increased number of mouse airway goblet cells (18-20). Recently, however, it was shown that sensitized Th2 cells and ovalbumin could induce mucus hyperplasia in mouse airways even when Th2 cells failed to express IL4 or IL-5 (17). Our results are consistent with this because they show that antibodies directed against IL-4 receptor (not shown) or IL-5 receptor failed to inhibit the response to dog BAL.

Our studies are performed on a simplified in vitro model of the mammalian airway. To confirm that the stimulation of mucin production by IL-9 occurs in vivo as well as in vitro, we administered rmIL-9 to mice intratracheally. Consistent with the in vitro data, we found that mice receiving IL-9 intratracheally showed an increased number of mucous cells in their tracheas and main stem bronchi 1 week later. This indicates that the ability of IL-9 to stimulate mucin in vitro is reflective of a biological phenomenon that also occurs in vivo.

How does IL-9 exert its effect on mucin synthesis? It is clear from the work of Kay et al. (13) that Th2 lymphocytes are present in asthmatic airways in numbers exceeding those found in normal airways. Moreover, the adoptive transfer experiments of Cohn et al. (24) indicate

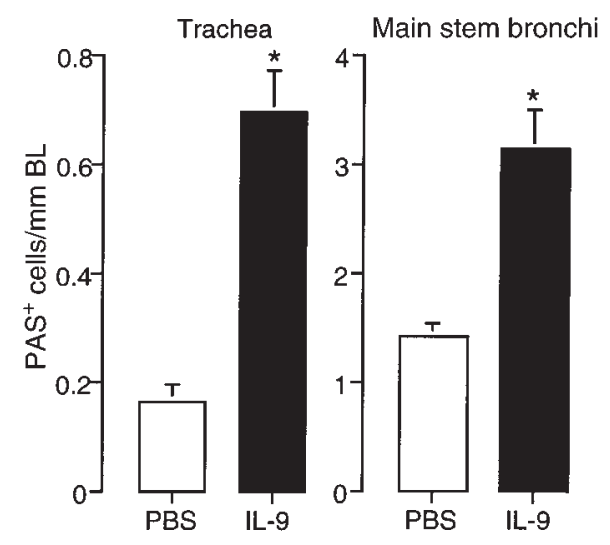

Figure 9

Tracheal instillation of rmIL-9 in C57BL6/J mice. The mean number $\left( \pm\right.$ SEM) of PAS-positive $\left(\mathrm{PAS}^{+}\right)$cells per millimeter basal lamina in the trachea and mainstem bronchi of mice instilled with $100 \mu \mathrm{L}$ of either IL-9 $(10 \mu \mathrm{g} / \mathrm{mL}$ in PBS; solid bars) or PBS (open bars). * Significantly different from PBS-instilled; $P<0.05$. 
that Th2 cells, which release IL- 9 , contribute to mucin overproduction in an animal model of the disease. Shimbara et al. (25) have recently shown that the IL-9 message is dramatically increased in the human asthmatic airway, and the primary source of this cytokine is activated Th2 lymphocytes. Although IL-9 effects had been described previously for only hematopoietic cells, our data reveal both IL-9 receptors and IL-9 responsiveness in epithelial cells. We have shown that IL-9 receptors are present on airway epithelial cells, but a preliminary comparison of asthmatic and normal bronchial biopsies suggests that the number of IL-9 receptors is not increased in asthma. This is supported by observations by Shimbara et al. (25) of asthmatic bronchial biopsy tissue. This strongly suggests that Th2 cell-released IL-9 activates epithelial IL-9 receptors that are normally present on airway epithelium, this in turn triggers a signaling cascade that activates MUC5AC transcription. Notably, the studies here consider only 1 of the 9 known human mucin genes. It is possible that other mucin genes are upregulated in asthma by other cytokines.

The effects of IL-9 on hematopoietic cells (e.g., mast cells and lymphocytes) are mediated by JAK/STAT signaling pathways (26). Because there is no previous evidence for IL9 effects on epithelial cells, the nature of the relevant signaling cascades is unknown. Analysis of the IL-9 signaling pathway in epithelial cells may suggest novel therapeutic approaches to the treatment of mucus hypersecretion.

\section{Acknowledgments}

We thank Elizabeth Matovinovic and Svetlana Resnik for excellent technical support. We also thank Peter O'Hara for instruction and advice in the use of his image analysis system. This work was funded by grants P01HL24136 and R01HL43762 from the National Heart, Lung, and Blood Institute (NHLBI), an award from Syntex Inc. (Division of Roche Bioscience) to C. Basbaum, and NHLBI grant R01HL61662 to J.V. Fahy.

1. Fahy, J.V., Steiger, D.J., Liu, J., Basbaum, C.B., Finkbeiner, W.E., and Boushey, H.A. 1993. Markers of mucus secretion and DNA levels in induced sputum from asthmatic and from health subjects. Am. Rev. Respir. Dis. 147:1132-1137.

2. Thurlbeck, W.M. 1973. Small airways disease. Hum. Pathol. 4:150-152.

3. Takizawa, T., and Thurlbeck, W. 1971. Muscle and mucous gland size in the major bronchi of patients with chronic bronchitis, asthma and asthmatic bronchitis. Am. Rev. Respir. Dis. 104:331-336.

4. Reid, L. 1954. Pathology of chronic bronchitis. Lancet. 1:275-278.

5. Sperber, K., Goswami, S.K., Gollub, E., Mayer, L., and Marom, Z. 1991. Mucus secretagogue production by a human macrophage hybridoma. J. Allergy Clin. Immunol. 87:490-498.

6. Gollub, E.G., Goswami, S.K., Sperber, K., and Marom, Z. 1992. Isolation and characterization of a macrophage-derived high molecular weight protein involved in the regulation of mucus-like glycoconjugate secre- tion. J. Allergy Clin. Immunol. 89:696-702.

7. Larivée, P., et al. 1994. Platelet-activating factor induces airway mucin release via activation of protein kinase C: evidence for translocation of protein kinase C to membranes. Am. J. Respir. Cell Mol. Biol. 11:199-205.

8. Larivée, P., Levine, S.J., Rieves, R.D., and Shelhamer, J.H. 1994. Airway inflammation and mucus hypersecretion. In Airway secretion: physiological bases for the control of mucus bypersecretion. S. Shimura and T. Takishima, editors. Marcel Dekker Inc. New York, NY. 469-511.

9. Baraniuk, J.N., and Kaliner, M.A. 1990. Neuropeptides and nasal secretions. J. Allergy Clin. Immunol. 86:620-627.

10. Levine, S.J., et al. 1995. Tumor necrosis factor- $\alpha$ induces mucin hypersecretion and MUC-2 gene expression by human airway epithelial cells. Am. J. Respir. Cell Mol. Biol. 12:196-204.

11. Robinson, D., et al. 1993. Activation of CD4+ T cells, increased Th2-type cytokine mRNA expression, and eosinophil recruitment in bronchoalveolar lavage after allergen inhalation challenge in patients with atopic asthma. J. Allergy Clin. Immunol. 92:313-324.

12. Wilson, J.W., Djukanovic, R., Howarth, P.H., and Holgate, S.T. 1992. Lymphocyte activation in bronchoalveolar lavage and peripheral blood in atopic asthma. N. Engl. J. Med. 326:298-304.

13. Kay, A.B., Barata, L., Meng, Q., Durham, S.R., and Ying, S. 1997. Eosinophils and eosinophil-associated cytokines in allergic asthma. Int. Arch. Allergy Immunol. 113:196-199.

14. Nakajima, H., et al. 1992. CD4+ T-lymphocytes and interleukin-5 mediate antigen-induced eosinophil infiltration into mouse trachea. Am. Rev. Respir. Dis. 146:374-377.

15. Kim, J., Woods, A., Becker-Dunn, E., and Bottomly, K. 1985. Distinct functional phenotypes of cloned Ia-restricted helper T-cells. J. Exp. Med. 162:188-201.

16. Mosmann, T.R., Cherwinski, H., Bond, M., Giedlin, M.A., and Coffman, R.L. 1986. Two types of murine helper T-cell clones. J. Immunol. 136:2348-2357.

17. Cohn, L., Homer, R.J., Marinov, A., Rankin, J., and Bottomly, K. 1997. Induction of airway mucus production by T Helper 2 (Th2) cells: a critical role for interleukin 4 in cell recruitment but not mucus production. J. Exp. Med. 186:1737-1747.

18. Temann, U.A., et al. 1997. A novel role for murine IL-4 in vivo: induction of MUC5AC gene expression and mucin hypersecretion. Am. J. Respir. Cell Mol. Biol. 16:471-478.

19. Temann, U.A., Geba, G.P., Rankin, J.A., and Flavell, R.A. 1998. Expression of interleukin 9 in the lungs of transgenic mice causes airway inflammation, mast cell hyperplasia, and bronchial hyperresponsiveness. J. Exp. Med. 188:1307-1320.

20. Kung, T.T., et al. 1995. Involvement of IL-5 in a murine model of allergic pulmonary inflammation: prophylactic and therapeutic effect of an anti-IL-5 antibody. Am. J. Respir. Cell Mol. Biol. 13:360-365.

21. Collie, D.D., DeBoer, D.J., Muggenburg, B.A., and Bice, D.E. 1997. Evaluation of association of blood and bronchoalveolar lavage eosinophil numbers and serum total immunoglobulin E concentration with the expression of nonspecific airway hyperreactivity in dogs. Am. J. Vet. Res. 58:34-39.

22. Li, D., Gallup, M., Fan, N., Szymkowski, D.E., and Basbaum, C.B. 1998. Cloning of the amino terminal and 5 -flanking region of the human MUC5AC mucin gene and transcriptional up-regulation by bacterial exoproducts. J. Biol. Chem. 273:6812-6820.

23. Zar, J.H. 1984. Biostatistical analysis. 2nd edition. Prentice-Hall. Englewood Cliffs, NJ. 50-70.

24. Cohn, L., et al. 1999. Th2-induced airway mucus production is dependent on IL-4R $\alpha$, but not on eosinophils. J. Immunol. 162:6178-6183.

25. Shimbara, A., et al. 1999. IL-9 and its receptor in allergic and non-allergic lung disease: increased expression in asthma. Am. J. Resp. Crit. Care Med. 159:A854. (Abstr.)

26. Bauer, J.H., Liu, K.D., You, Y., Lai, S.Y., and Goldsmith, M.A. 1998. Heteromerization of the $\gamma_{c}$ chain with the interleukin-9 receptor $\alpha$ subunit leads to STAT activation and prevention of apoptosis. J. Biol. Chem. 273:9255-9260.

27. Curfs, J.H.A.J., Meis, J.F.G.M., and Hoogkamp-Korstanje, J.A.A. 1997. A primer on cytokines: sources, receptors, effects and inducers. Clin. Microbiol. Rev. 10:742-780. 